\title{
Estudo e reflexão sobre a linguagem no Ensino Religioso
}

\author{
Study and reflection on language \\ in Religious Education
}

\author{
Sérgio Rogério Azevedo Junqueira*
}

\begin{abstract}
Resumo: Alguns elmentos são necessários para a compreensão do Ensino Religioso como um componente curricular, dentre os quais encontra-se a questão da linguagem. Essa temática foi abordada formalmente por Wolfgang Gruen na década de mil novecentos e oitenta. Todavia, em decorrência das discussões e estruturação da Base Nacional Curricular, torna-se necessário a retomada dos estudos sobre esse elemento constitutivo de um componente curricular. Este artigo parte do resultado de uma pesquisa qualitativa e bibliográfica realizada a partir de publicaçôes acadêmicas identificadas no Projeto Mapa da Produção Científica, visando verificar e sistematizar os aspectos teóricos sobre a questão da linguagem. Foram abordadas a questão da compreensão e aquisiçẫo da linguagem, bem como aspectos da linguagem religiosa e sua relação específica com o Ensino Religioso. Portanto, este texto tem a pretensão de contextualizar a questáo da linguagem no cenário dos estudos sobre o Ensino Religioso, porém compreende que, para ampliar posteriormente este trabalho, é necessário ampliar o campo de diálogo com áreas como a Comunicação, Filosofia da Linguagem e outras que permitam aprofundar a tem.
\end{abstract}

Palavras-chave: Educação. Linguagem. Ensino Religioso.

Abstract: Some elements are necessary for the understanding of religious teaching as a curricular component, among which is the question of language. This theme was formally approached by Wolfgang Gruen in the 1980s, but as a result of the discussions and structuring of the National Curricular Base, it is necessary to resume studies on this constituent element of a curricular component. This article is the result of a qualitative and bibliographical research carried out from academic publications identified in the Scientific Production Map Project, aiming at verifying and systematizing the theoretical aspects on the question of linguistics as: comprehension, typology, religious language and its specific relation with religious teaching. Therefore, this text has the pretension of contextualizing the question of language in the scenario of studies on religious teaching, but understands that to expand later this work is necessary to broaden the field of dialogue with areas such as communication, philosophy of language and others that allow to deepen the thematic of the language and the didactic transposition for the pedagogical doing of the curricular component.

Keywords: Education. Language. Religious Education.

\section{Introdução}

No ano de 1997, o Conselho Nacional de Educação, em sua proposta de regulamentação da Lei No 9.394/96 unificou pelo texto o termo "outros componentes curriculares" como disciplina, estudo, conhecimento, ensino, matéria, conteúdo curricular. A partir dessa compreensão, percebe-se os valores fundamentais ao interesse social, direitos e deveres dos cidadáos, envolvendo respeito ao bem comum e à ordem democrática,

Livre Docente em Ciência da Religião (PUC-SP), doutor em Ciências da Educação (Universidade Pontificia Salesiana, Roma), líder do GPER. Contato: srjunq@gmail.com 
como fundamentos da sociedade abrangendo a formação de atitudes, preparação para o trabalho, para a cidadania e para a ética nas relaçôes humanas (Parecer CNE/CEB no 5/97). Ou seja, os saberes elaborados pela humanidade e as referências do mundo no qual o estudante está inserido apresentam especificidades e saberes próprios construídos e sistematizados.

Por sua vez, cada componente curricular compreende fenômenos específicos que favorecem o enfrentamento de situaçôes a partir da construção de argumentaçóes com linguagem específica para cada saber, pois, como é proposto pela Lei 9394/96 em seu segundo parágrafo, essa educaçáo tem por finalidade que o pleno desenvolvimento do educando, seu preparo para o exercício da cidadania e sua qualificação para o trabalho sejam alcançados nos diferentes sistemas de ensino do país. Tal finalidade foi confirmada com o texto homologado em 2017 da Base Nacional Comum Curricular, que afirma: "[...] cada componente curricular apresenta um conjunto de habilidades. Essas habilidades estão relacionadas a diferentes objetos de conhecimento - aqui entendidos como conteúdos, conceitos e processos" (BNCC, 2017, p. 26). Efetivamente, cada componente curricular vinculado a uma ciência particular apresenta um código intrínseco, uma lógica interna, métodos próprios de investigação, que se expressam nas teorias e nos modelos construídos para interpretar os fenômenos que se propóe a explicar. Apropriar-se desses códigos, dos conceitos e métodos relacionados a cada uma das ciências, compreender a relação entre ciência, tecnologia e sociedade, significa ampliar as possibilidades de compreensão e participação efetiva nesse mundo (PCN - Ensino Médio - Bases Legais Distrito Federal: MEC, 1997, p. 12).

Um dos elementos de um componente curricular é a linguagem, pois quanto mais diversificado for o repertório específico de cada saber a ser construído pelos alunos, mais se ampliará a produçáo de sentidos na leitura de mundo. O que favorecerá a compreensão das particularidades da linguagem, em suas potencialidades e em suas limitações, conduzindo ao "reconhecimento dos produtos dessas linguagens náo como verdades, mas como possibilidades" (BNCC, 2017, p. 359).

É aqui que a pertinência deste artigo se estabelece. A partir das discussões e estruturação da Base Nacional Curricular, retomam-se os estudos sobre este elemento constitutivo deste componente curricular. $\mathrm{O}$ conhecimento religioso, objeto da área de Ensino Religioso, é produzido no âmbito das diferentes áreas do conhecimento científico das Ciências Humanas e Sociais, notadamente da Ciência da Religião. Essas Ciências investigam a manifestaçáo dos fenômenos religiosos em diferentes culturas e sociedades enquanto um dos bens simbólicos resultantes da busca humana por respostas aos enigmas do mundo, da vida e da morte. De modo singular, complexo e diverso, esses fenômenos alicerçaram distintos sentidos e significados de vida e diversas ideias de divindade(s), em torno dos quais se organizaram cosmovisóes, linguagens, saberes, crenças, mitologias, narrativas, textos, símbolos, ritos, doutrinas, tradiçóes, movimentos, práticas e princípios éticos e morais. Os fenômenos religiosos, em suas múltiplas manifestaçôes, são parte integrante do substrato cultural da humanidade.

O ponto de partida deste artigo é uma pesquisa qualitativa e bibliográfica realizada a partir de publicaçôes acadêmicas identificadas no Projeto Mapa da Produçáo Científica. A equipe que elaborou o Mapa da Produção Científica do Ensino Religioso no Brasil 
no período de 1914 a 2017 (Junqueira et al., 2018), tendo como critério de identificação que o título e/ou nas palavras-chave explicitassem os termos "Ensino Religioso" e "Linguagem", localizou as seguintes publicaçóes entre os anos de 1991 e 2015:

\section{Tabela 1 - Publicaçóes sobre Linguagem e Ensino Religioso.}

\begin{tabular}{|c|c|c|c|}
\hline Francisco Catão & $\begin{array}{l}\text { A linguagem do } \\
\text { Ensino Religioso }\end{array}$ & $\begin{array}{c}\text { Revista de Catequese, } \\
\text { Ano 14, No } 56 \\
\end{array}$ & 1991 \\
\hline Giseli do Prado Siqueira & Linguagem do Ensino Religioso & $\begin{array}{l}\text { Universidade Regional } \\
\text { de Blumenau. } \\
\text { Orientador Hilário } \\
\text { Inácio Bohn. } \\
\end{array}$ & 1998 \\
\hline Teresinha Maria Mocellin & $\begin{array}{l}\text { A linguagem no Ensino } \\
\text { Religioso: limites e } \\
\text { possibilidades }\end{array}$ & $\begin{array}{l}\text { Encontro do GT } \\
\text { nacional de História } \\
\text { das Religiōes e das } \\
\text { Religiosidades / } \\
\text { ANPUH, UEM }\end{array}$ & 2007 \\
\hline Viviane Cristina Cândido & $\begin{array}{c}\text { Haveria um jogo de linguagem } \\
\text { específico para o Ensino } \\
\text { Religioso? - uma análise } \\
\text { dos Parâmetros curriculares } \\
\text { nacionais para o ER como fonte } \\
\text { do discurso dessa disciplina } \\
\end{array}$ & $\begin{array}{l}\text { Encontro do GT } \\
\text { nacional de História } \\
\text { das Religióes e das } \\
\text { Religiosidades / } \\
\text { ANPUH, UEM }\end{array}$ & 2007 \\
\hline $\begin{array}{l}\text { Lílian Blanck de Oliveira, } \\
\text { Simone Riske Koch }\end{array}$ & $\begin{array}{c}\text { Linguagem e diferença: espaços } \\
\text { e encontros na formação } \\
\text { em Ensino Religioso }\end{array}$ & $\begin{array}{l}\text { Diálogo Educacional. } \\
\text { V. } 08, \text { N. } 23 .\end{array}$ & 2008 \\
\hline $\begin{array}{l}\text { Simone Riske Koch, } \\
\text { Dolores Henn Fontanive, } \\
\text { Elcio Cecchetti }\end{array}$ & $\begin{array}{l}\text { Linguagem, diferença } \\
\text { e dignidade: espaços e } \\
\text { encontros na diversidade. }\end{array}$ & $\begin{array}{c}\text { III Simpósio } \\
\text { Internacional sobre } \\
\text { Religiosidades, } \\
\text { Diálogos Culturais e } \\
\text { hibridaçóes. UFSM }\end{array}$ & 2009 \\
\hline Gleyds Silva Domingues & $\begin{array}{l}\text { Cultura e linguagem: em } \\
\text { busca da diversidade no } \\
\text { currículo do Ensino Religioso }\end{array}$ & Salão de Pesquisa EST & 2011 \\
\hline Arthur Felipe Moreira de Melo & $\begin{array}{c}\text { Linguagem e Sincretismo: } \\
\text { Reflexos no Ensino Religioso }\end{array}$ & $\begin{array}{l}\text { IV Congresso da } \\
\text { Anptecre, UNICAP }\end{array}$ & 2013 \\
\hline $\begin{array}{l}\text { Josilene Silva da Cruz, } \\
\text { Eunice Simôes Lins Gomes }\end{array}$ & $\begin{array}{l}\text { A linguagem simbólica como } \\
\text { proposta metodológica } \\
\text { para o Ensino Religioso }\end{array}$ & $\begin{array}{l}\text { II Seminário FIDELID: } \\
\text { Diálogo e reflexão } \\
\text { do Ensino Religioso } \\
\text { na escola, UFPB }\end{array}$ & 2015 \\
\hline
\end{tabular}

Fonte: JUNQUEIRA, S. et al. Socialização do saber: produção científica do Ensino Religioso. Porto Alegre: Editora FI, 2018.

A partir dos pressupostos de uma exigência para a composiçáo de um componente curricular e dos trabalhos publicados sobre a temática da Linguagem e o Ensino Religioso é que se retomam elementos abordados pelos pesquisadores que já socializaram seus estudos entre 1988 a 2015, visando uma discussáo sobre linguagem no campo do Ensino Religioso.

O tema da linguagem no Ensino Religioso como um dos componentes curriculares é percebido desde o primeiro registro para implementar esse componente no espaço escolar, sistematizado por Wolfgang Gruen em 1988 em seu artigo "A natureza do 
Ensino Religioso: a luz de uma aula", publicado na Revista de Catequese (Ano 11 N. 44, pp. 05-16). De forma provocativa, o autor expõe uma aula sobre a figura de Maria ministrada em uma "cidadezinha de Minas" por um professor que identifica que a problemática não se encontra no tema a ser explorado com os estudantes, mas em como ele é focado. $\mathrm{O}$ autor do artigo demonstrou que o uso de uma linguagem que náo privilegia um grupo e náo discrimina os demais favorece o estudo de aspectos da cultura brasileira (Gruen, 1988, pp. 8-9).

Vê-se um ponto comum entre as produçóes apresentadas na Tabela 1: uma linguagem que considera a diversidade cultural e religiosa sem, no entanto, descuidar da linguagem simbólica presente no universo religioso. Os estudos de Catão (1991, pp. 9-11) e de Mocellin (2007, pp. 3-5) discutindo a concepção, a tipologia e a especificidade da linguagem religiosa como elementos que expressam o processo de comunicaçáo que ocorre efetivamente em todos os espaços sociais, destacam a escola, espaço de construção coletiva de conhecimentos onde a proposta pedagógica possibilita a articulação dos conteúdos de ensino e de aprendizagem, com vivências e indagaçóes do professor e dos alunos sobre a realidade em que vivem.

Dessa forma, pretende-se apresentar algumas consideraçóes dos autores das produçōes elencadas para, assim, prosseguir na reflexão sobre a linguagem no Ensino Religioso.

A partir desses estudos será possível rever e reorganizar os referenciais para atualizar a discussão sobre como a mediação dos componentes curriculares favorece uma comunicação entre os saberes elaborados pela humanidade e as referências do mundo no qual o estudante está inserido. Tais componentes apresentam especificidades e saberes próprios construídos e sistematizados. Especificamente, um dos elementos para estabelecer esses componentes curriculares é o domínio de linguagens. Para esse estudo, o interesse é sobre a linguagem no Ensino Religioso, que assume a Ciência da Religião como ciência de referência.

\section{Linguagem: compreensão}

Motivo de atenção já entre os filósofos gregos, a reflexão sobre a linguagem e seu desenvolvimento vai se constituindo por meio dos sujeitos em um processo de desenvolvimento da própria linguagem e da comunicação entre os seres humanos, e passa a ser a possibilidade concreta de que os dados da realidade cheguem à consciência.

Para Aristóteles (384-324 a.C.) a linguagem permite ao ser humano estabelecer relaçóes pertinentes para o seu desenvolvimento. Ele ainda designa o ser humano como zoom-logon-echon, ou seja, com um ser vivente que dispóe de logo, linguagem e razão.

Assim, o homem é um animal cívico, mais social do que as abelhas e os outros animais que vivem juntos. A natureza, que nada faz em vão, concedeu apenas a ele o dom da palavra, que não devemos confundir com os sons da voz. Estes são apenas a expressão de sensações agradáveis ou desagradáveis, de que os outros animais são, como nós, capazes. A natureza deu-lhes um órgão limitado a este único efeito; nós, porém, temos a mais, senão o conhecimento desenvolvido, pelo menos o sentimento obscuro do bem e do mal, do útil e do nocivo, do justo e do injusto, objetos para a manifestaçáo dos quais nos foi principalmente dado o órgão da fala. Este comércio da palavra é o laço de toda sociedade doméstica e civil (Aristóteles, Política 1, 2, 1253). 
Assim, a linguagem é constituidora do sujeito mesmo que de forma indireta, pois precisa passar primeiro pelos significados e depois por palavras. Dessa forma, o sentido é gerado por motivaçôes, desejos e necessidades, interesses e emoções (Trenti, 1990, p. 120). Contudo, para compreender a fala de outros, não é suficiente entender as palavras, mas é necessário também compreender o contexto cultural, considerando que as palavras adquirem o seu sentido no cenário em que surgem. Alterando o cenário, os significados também são modificados (Lopes, 2016, p. 02).

Considerando que a linguagem não é uma coisa pronta, mas um processo contínuo - é o esforço reiterado da mente humana no sentido de usar sons para expressar pensamentos -, isto efetivamente significa que a linguagem não está reduzida à capacidade de descrição das coisas, mas se refere abertura e revelação do ser (Lussi, 2011, p. 70).

Soma-se a essa complexidade o processo de globalização, que, pela facilidade de comunicaçáo e o acesso entre as culturas, pode alterar profundamente, e talvez definitivamente, o sentido das palavras. É certo que não aplica aqui a ideia de uma cultura universalizada mundialmente, mas ressalta-se a necessidade de se explicitar a expressáo das diferenças, estabelecendo o impacto do pluralismo nas sociedades (Shock, 2012, p. 47).

Os estudos de Koch (2007, pp. 37-39) introduzem o primeiro elemento identificado sobre a linguagem do Ensino Religioso, que é a questão da compreensão da linguagem que expressa, anuncia e pronuncia diferentes sentimentos e posturas de pessoas, culturas e povos que vão se organizando e expressando a relação que os circundam.

Em relação ao Ensino Religioso, é necessária a devida caracterização da sociedade brasileira, que apresenta uma rica diversidade cultural, e isso exige uma proposta de educação comprometida com uma perspectiva pluricultural, que busque a compreensão das linguagens identificadas ao longo do território nacional e as categorizaçóes desses perfis. Para Oliveira e Koch (2008, p. 257),

O contexto das culturas e das religióes é atravessado pelas diversidades, que as constituem historicamente. A linguagem busca expressar, anunciar e pronunciar os diferentes sentimentos e posturas que pessoas, culturas e povos vão organizando e expressando em relação ao que os circundam. Nesse sentido, expressões usadas no cotidiano e aparentemente tão simples quanto: religião, religiosidade, sagrado, fé e muitas outras trazem diferente sentidos em diferentes contextos sociais, políticos ou culturais.

Vale ressaltar que as práticas de significação, que perpassam práticas sociais e culturais, envolvem relaçôes de poder, inclusive a capacidade para definir quem é incluído e quem é excluído. E por isso as autoras também discutem a formação docente, "com vistas à construção de educadores comprometidos com a vida solidária em uma perspectiva de planetaridade" (Oliveira, Koch, 2008, p. 259). Ainda para as autoras, tal formação contempla o "exercício do diálogo, que busca identificar nos sentidos e significados dos sujeitos espaços e lugares para encontros nas diferenças".

Como a linguagem permite comunicar ideias, especificamente no Ensino Religioso, é necessária sua compreensão para dialogar e compreender o conceito de religião, que é o objeto de estudo de sua ciência referência.

Segundo Michel Meslin, o sistema de crenças e de prática, como um complexo das atividades humanas informadas pela fé, também perpassa o sentido horizontal 
designado como piedade, que implica não apenas atos de devoção para com Deus, mas também em ações para com a humanidade. Efetivamente, a religião é um modo de ordenar o mundo, facultando a compreensão de coisas muito complexas, como a ideia de tempo, a ideia de externo e a ideia de perda e desaparecimento, este mistério perene da existência humana (Meslin, 1992, p. 38).

Portanto, a linguagem expressa a relaçáo com o que transcende o ser humano. Como uma alternativa de explicaçáo da nossa relação com a realidade, enquanto relação de significação, a linguagem permite que se estabeleça a análise do significado e dos processos de simbolizaçấo, constituindo uma nova via na busca do fundamento, na busca de se encontrar um elemento mais básico.

\section{Linguagem: aquisiçáo e desenvolvimento}

Outros dois elementos importantes para o estudo da linguagem no Ensino Religioso são a aquisição e o desenvolvimento da linguagem, pois se faz necessária a compreensão social e cognitiva do estudante para que as situaçôes didáticas em sala de aula se concretizem. "No exercício de sua prática pedagógica o professor é o socializador, aquele que envolve o educando levando-o a interagir com o conhecimento dos conteúdos do ensino religioso, fazer leitura, descobrir e redescobrir" (Mocelin, 2007, p. 05).

Destacam-se, no campo da aprendizagem, as pesquisas de Jean Piaget (18961980), que conclui a existência de dois tipos de discursos: o egocêntrico e o socializado. Especialmente sobre o primeiro discurso, é importante verificar que não existe vida social persistente em crianças com menos de sete ou oito anos. Outro elemento é o de que a verdadeira linguagem social utilizada em suas atividades fundamentais é o jogo, que por meio de gestos, movimentos e mímica expressam uma linguagem de palavras. A comunicaçáo entre os sujeitos, na medida em que amplia sua convivência, pode promover a superação de seu egocentrismo. Entretanto, nesse processo de crescimento, verifica-se que situaçôes de dificuldade e conflito podem manter o sujeito voltado para si. Especificamente com as crianças menores de sete anos, Piaget notou o pensamento em termos de esquemas, que lhes permite concentrar-se na totalidade de uma mensagem sem que cada detalhe tenha de fazer sentido. Quando ouvem algo que elas náo entendem, as crianças não tentam analisar a estrutura da frase ou palavras, mas tentam compreender ou criar um significado geral, fantasiando ou usando sua imaginaçáo para explicar o que não compreenderam.

Piaget percebeu também que as crianças não se envolvem em pensamento dedutivo ou analítico, que não há nenhuma razão para fazer uma demarcação clara entre "o real" e "o não real". Como suas mentes não funcionam em termos de causalidade e provas, tudo parece possível. No "mundo do faz de conta", tudo faz sentido de acordo com suas próprias intençóes e motivaçóes. Na verdade, como Piaget observa ironicamente, o mundo da criança parece funcionar táo bem que, de acordo com seu próprio entendimento, a lógica não é obrigada a apoiá-lo (Montoya, 2006, pp. 120 -123).

A comunicação impóe um código comum ao emissor e ao receptor, e este código constitui a lingua. Pode ser reconstruído como o modelo que abrange diferentes 
realizaçóes observadas: estas constituem a fala, da qual se pode recolher um corpus para um indivíduo ou para uma população. Um mesmo indivíduo pode possuir múltiplos códigos: língua falada, língua escrita, gírias, linguagens técnicas, etc., que correspondem a diferentes sistemas de comunicação no grupo. Pode existir também aí aspectos sucessivos: a linguagem da criança pode evoluir: há uma história das línguas [...] (Fraisse, Piaget, 1969/VIII, p. 05).

É notório que as crianças sempre querem saber a intenção de todos e de tudo, mesmo que seja inanimado, e não percebem que apenas algumas coisas têm intençóes. Mais tarde, quando a criança pode perceber que a maioria das coisas é causada, em vez de pretendida, suas questóes tornam-se sobre a causalidade. $\mathrm{O}$ tempo de vida de uma criança antes que ela entenda causa e efeito - pré-causalidade - coincide com o tempo de egocentrismo. Os adultos muitas vezes têm dificuldade para compreender as crianças porque eles se esqueceram de que na criança existe uma mente completamente diferente, em que a lógica não desempenha nenhum papel. Não é possível fazer uma criança pensar da mesma maneira de um adulto. Em cada idade, a criança ganha certo equilíbrio em relação ao seu ambiente. Ou seja, a maneira como ela pensa e percebe aos 5 anos explica perfeitamente o seu mundo. Mas náo faz dessa mesma forma quando está com 8 anos. Assim como os seres humanos crescem fisicamente e se ajustam ao seu ambiente de acordo com os seus corpos, eles se ajustam intelectualmente.

Em escritos posteriores, Piaget explorou a fase final de desenvolvimento mental, começando aos 11 anos ou 12. A capacidade do adolescente de raciocinar, pensar abstratamente, fazer julgamentos e considerar as possibilidades futuras é essencialmente a mesma de um adulto. Desse ponto em diante, é uma questão de aumentos na capacidade em vez de mudanças qualitativas.

Vygotsky (1896-1934) trabalha com duas funçóes básicas da linguagem, sendo como principal a do intercâmbio social; visando comunicar com os demais é que o ser humano cria e utiliza sistemas de linguagem, pois é, de fato, a necessidade de comunicação que impulsiona o desenvolvimento da linguagem para expressar ideias, emoçóes e outras informaçóes. Sendo a outra função a do pensamento generalizante, em que a linguagem ordena o real, agrupando as ocorrências de humanas de classe, objetos, eventos e situaçóes com a mesma categoria conceitual. Pois, ao nomear um determinado objeto, estamos classificando esse objeto em uma categoria e, portanto, o diferenciando de outras categorias. Essa segunda função é que torna a linhagem um instrumento de pensamento, ou seja, a linguagem fornece os conceitos e as formas de organização do real que constituem a mediação entre o sujeito e o objeto do conhecimento (Montoya, 2006, pp. 124 -126).

$\mathrm{Na}$ perspectiva de Vygotsky, o pensamento e a linguagem têm origem e desenvolvimento diferentes e independentes, porém, em determinado momento do desenvolvimento humano, essas duas trajetórias se unem, o pensamento torna-se verbal e a linguagem, racional. Compreendendo que associação entre pensamento e linguagem é atribuída à necessidade do intercâmbio entre os indivíduos durante especificamente o trabalho, uma ação especificamente humana. Que exige planejamento, ação coletiva de transformação do espaço que ocupa, portanto, a necessidade de uma comunicaçáo social para articular o grupo. O surgimento do pensamento verbal e da linguagem como sistema de signos é compreendido como crucial no desenvolvimento da espécie humana (Oliveira, 1993, pp. 42-45): 
Mas a mais importante descoberta é o fato de em determinado momento por alturas dos dois anos de idade, as curvas de desenvolvimento do pensamento e da linguagem, até entáo separadas, se tocarem e fundirem, dando início a uma nova forma de comportamento. Foi Stern quem pela primeira vez e da melhor forma nos deu uma descriçáo deste momentoso acontecimento. Ele mostrou como a vontade de dominar a linguagem se segue à primeira compreensão difusa dos propósitos desta, quando a criança "faz a maior descoberta da sua vida", a de que "todas as coisas têm um nome". Este momento crucial, quando a linguagem começa a servir o intelecto e os pensamentos começam a oralizar-se, é indicado por dois sintomas objetivos que não deixam lugar a dúvidas: a súbita e ativa curiosidade da criança pelas palavras, as suas perguntas acerca de todas as coisas novas ("o que é isto?") e, o consequente enriquecimento do vocabulário que progride por saltos e muito rapidamente [...] (Vygotsky, 2002, p. 63).

Assim, no estudo da linguagem encontram-se as funções relativas a como os indivíduos transmitem sua mensagem, que pode ser para expressar sentimentos, informaçôes e influências a outros indivíduos. A partir do exposto sobre a aquisição e desenvolvimento da linguagem, apresentamos algumas consideraçóes de Mocelin (2007) e Cândido (2007) para a linguagem no Ensino Religioso.

Para Cândido $(2007,4)$,

O conhecimento religioso possui dois níveis, que são o conhecimento adquirido pela experiência pessoal e o conhecimento adquirido por meio de informaçóes. Na questáo da legitimidade destes conhecimentos, aponta que no campo da filosofia e da teologia a legitimidade do conhecimento está na razão e na autoridade, diferentemente de outras ciências que se legitimam no rigor do método. Fica então a questão da veracidade da dimensão religiosa do conhecimento humano, que tem duas vertentes: aquela que se enraíza na autoridade, institucional ou carismática, e aquela que provém do próprio interrogante.

Vê-se, assim, o quanto é importante considerar o desenvolvimento do estudante para atender sua curiosidade e legitimar sua dimensão religiosa. Ainda para Cândido, a escola é o espaço de construção do saber e "cabe à escola conhecer e valorizar a trajetória particular dos grupos que compóem a sociedade brasileira, sem o que não poderá colaborar com o educando na busca pelas respostas" (Cândido, 2007, p. 04).

Como a linguagem está presente no processo de perceber e avaliar as situações, para Mocelin (2007, p. 04) "toda reflexão está ligada, incondicionalmente, ao alcance da atuação e compreensão da linguagem como espaço de expressividade”. Outro aspecto abordado por Mocelin é a função da linguagem.

A partir da segunda metade do século XX, vários pensadores, se manifestaram sobre a função da linguagem. Dentre eles, Wittgenstein que, em sua renomada obra Investigaçōes Filosóficas - abriu uma nova visão na área das ciências, cujo saber forçou um novo olhar sobre as religióes, que aqui corresponde em larga parte, à função da linguagem no ensino religioso, disciplina que exige ampla compreensão e uso corrente da linguagem em sua aparente transparência (Mocelin, 2007).

Identifica-se que a linguagem é uma construção do ser humano, mas só é possível na interação social, pois envolve a experiência afetiva de abrir-se ao sentido do outro. Depende de fatores endógenos (desenvolvimento do pensamento) e exógenos (interferência significativa e estimulante do meio ambiente). É o sentido religioso que vai permitir a cada um, inicialmente, descobrir a própria linguagem verbal ou simbólica para comunicar-se espontaneamente com o transcendente. À medida que o ser humano 
desenvolve sua inserção na comunidade religiosa, esta lhe permitirá a utilização significativa dos símbolos comuns da religião.

Compreendendo que a abordagem dos conteúdos estabelecida pela linguagem é tão significativa quanto as informaçōes, percebe-se que a atitude de uma pessoa diante do fenômeno religioso não é apenas o resultado de conhecimentos e de racionalizaçáo, nem um procedimento exclusivamente de ordem psicológica.

\section{Linguagem religiosa}

O terceiro elemento é a especificidade da linguagem religiosa, que permite ressignificar em diferentes campos, entre os quais o da linguagem religiosa. Esta se mostra ao longo dos tempos como um poderoso instrumento de manipulação, que é utilizado por indivíduos e grupos sociais de forma ilusória, perigosa, falsa e destituída de valores (Rabuske, 1984, p. 152.). A linguagem religiosa se apresenta por meio de diversos gêneros literários, como poético, narrativo, jurídico, profético, sapiencial, parenético ${ }^{1}$ etc. Ampliando a compreensão de objetos, textos que se alternam entre linguagens literais e simbólicas, e são determinantes para a assimilação dos conteúdos, o religioso se torna portador de uma linguagem capaz de encaminhar a outros uma experiência divina reinterpretando e reorganizando os significados (Trenti, 1993, p. 82).

Verifica-se que, ao mesmo tempo em que o ser humano experimenta o sagrado quando crê, ele o vê além de sua realidade física. Assim, quando se estudam elementos que dizem respeito a tudo que é transcendente, incognoscível, inominável, divino, explora-se um domínio existente como experiência pessoal, e náo limitado à esfera do mundo físico. É inegável que o sagrado influencia muitas pessoas e está inserido no cotidiano da humanidade. Trata-se de um mistério que náo se restringe a um universo palpável, mas declara concretamente sua existência por meio das reaçóes e dos sentimentos vividos por homens diante dele. $\mathrm{O}$ sagrado também se apresenta verbalmente aos homens por meio de livros vistos como de origem divina. A maioria das religióes, além de possuir seus rituais e normas, é regida por esses textos considerados sagrados. São escritos antigos que até hoje influenciam homens, determinando normas e regras de comportamento. Além disso, assumem um valor não só instrucional, mas também emocional, tendo em vista o apego e o respeito que as pessoas assumem diante de um texto sagrado (Lopes, 2009, p. 63).

Os discursos religiosos se mostram com estruturas rígidas quanto aos papéis dos interlocutores (a divindade e os seres humanos), assim como os dogmas sagrados; por exemplo, fé e Deus são intocáveis. Além do que, se verificam duas características do discurso religioso: a primeira é a intertextualidade, ou seja, o discurso religioso (pela sua natureza) tem a ver com outro discurso religioso; a segunda característica é de um discurso profético que explora as dimensôes de espaço e tempo que caracterizam a dissimulação no discurso profético da relaçáo com o momento histórico como possibilidade mesma de constituir-se que é aplicada em trechos de oração, de sermóes (Bahnsen, 2008, p. 2.).

1 A linguagem parenética é a linguagem utilizada em sermões. Consiste na arte de pregar, de discursar por meio de eloquência sacra, sagrada ou religiosa. 


\section{4

Portanto, a linguagem religiosa está incluída no mesmo padrão de linguística com o fato de estar muito ligada à emoção, à forma de expressarem sentimentos (Boas, Manzatto, 2015, p. 9). Dessa forma, na contemporaneidade, a linguagem é uma alternativa de explicação da nossa relação com a realidade enquanto relação de significação. A análise do significado e de nossos processos de simbolização constitui-se em uma nova via na busca do fundamento, de se encontrar um elemento mais básico. É significativo, portanto, que a questão sobre a natureza da linguagem, sobre como a linguagem fala do real, sobre o sentido dos signos e proposiçóes linguísticas, emerge como um problema central.

Discutir sobre Deus ou Deuses como uma ação cultural e histórica, que se encontra sempre no meio de uma determinada tradição transmitida de forma oral e escrita. O que significa nunca ter acesso imediato aos oráculos divinos, verificando que, no melhor dos sentidos, a palavra divina é circunstancial. Tais circunstâncias em cada momento desvelam as dimensóes da palavra divina e de suas exigências. Por esse motivo, a revelação de magnitude histórica significa a necessidade precisa de interpretação, ou seja, de adequação espaço-temporal (Chervalier, Gheerbrant, 1998, p. 551). Esta leitura dos textos teológicos problematizada favorece uma leitura que permitirá a passagem do geral e do abstrato ao concreto e imediato: ou seja, a palavra divina se encarna e adquire vigência em um aqui e agora com fisionomia própria e contextualizada (Amatuzzi, 2003, p. 69.). Verifica-se a que hermenêutica náo se relaciona apenas a tais textos, é considerado na constituiçáo múltipla do ser humano, e a realidade do divino, do humano e do mundo, em cada momento histórico, se expressa polifonicamente no meio da complementariedade das dicções e expressóes. A linguagem é fruto da interpretação do fenômeno religioso que, ao mesmo tempo, conjuga pensamento crítico, ação eficaz e experiência espiritual tornando possível o restabelecimento criativo, ecológico, pacífico e poético da relaçáo entre mística e política. O crer, o fazer e o experimentar devem se reinventar, a cada dia, já que são atividades humanas. Interpretar na Teologia e Ciência da Religiáo, como ação que interpreta conduzida pelos sinais dos tempos, também devem levar em conta o momento social inerente a qualquer hermenêutica criadora. Não são sujeitos, individualmente, que leem e interpretam os textos teológicos: são as comunidades. Isso significa que uma comunidade religiosa existe se há comunhão real entre seus membros. O momento social, ao qual se alude, pode se concretizar também, mediante a noção de diálogo. Uma hermenêutica compassada aos "sinais dos tempos" institui diálogo, cuja característica mais relevante é o consenso na verdade. Não o consenso baseado em prática estratégica da compensaçáo, mas aquele consenso que se origina no reconhecimento do direito a ser diferente, no inevitável caráter construtivista da realidade e da norma (Pinto, 2002, pp. 84-85).

Diante desse contexto, é possível compreender as funçóes da linguagem e os serviços religiosos aplicados:

a. A função emotiva por meio do contato do divino com o ser humano expressando as emoções, cultos de oração, ação de graças, em momentos de confraternização entre os membros dos momentos solenes quando do interior que se encontra com o exterior por meio de palavras; estes momentos em que o ser humano reconhece a dependência e o alcance do divino, aplicados aos momentos de oração, reflexão, cântico, confraternização. 
b. A função apelativa é o esforço de influenciar por meio de uma linguagem argumentativa com a intencionalidade de influenciar o comportamento do destinatário. Dessa forma, todo emissor, ao produzir uma mensagem, esforça-se no sentido de adaptar as características sociais e psicológicas do que vai receber. Pois, afirma-se que o texto traz, de alguma forma, as manifestaçôes da função conativa da linguagem. É aplicada em estudos bíblicos, campanhas evangélicas, sermóes, histórias infantis de cunho moral.

c. A função referencial é centrada no referente, ou seja, no objetivo, ou seja, na situação a que se refere à mensagem, pois existe a preocupação em informar os dados da realidade, na transmissão de informaçóes. Por esse motivo existe uma preocupação em uma linguagem objetiva, impessoal e denotativa. Aplica-se na agenda de igrejas, palestras, estudos doutrinários.

d. A função metalinguística caracteriza-se por utilizar códigos para explicar elementos do próprio código, ou seja, é uma recodificação, para verificar se o emissor e receptor estáo usando o mesmo repertório; portanto, é uma mensagem codificada. Utilizada nos cultos evangelísticos, classes bíblicas, escolas sabatinas, classes de professores, estudos apocalípticos.

e. A função fática é centrada no canal de comunicação ou no contato, visando estabelecer, manter ou mesmo interromper o processo comunicativo com a intençáo de testar o canal, testar a própria comunicação. Verifica-se nos cumprimentos, linguagem dos gestos, abraços, apertos de mão.

f. A função poética é a maneira como a linguagem é trabalhada; esta função ocorre tanto na prosa quanto na poesia, e está identificada na forma e estrutura da mensagem reforçando ou modificando o conteúdo veiculado por esta mensagem, com força na conotação e no subjetivismo. Foi aplicada nos cânticos, salmos, poemas, releitura dos textos bíblicos e atitudes religiosas com base nos atos da fala.

Nesse processo, a palavra é uma realidade dotada de poder, com eficácia que transfere as relaçóes do texto para o cotidiano da comunidade, como alimento dos que têm o desejo da justiça em diferentes culturas (Setzer, 1987, pp. 91-96).

Efetivamente para articular o conteúdo e a metodologia do Ensino Religioso, é necessário a compreensão da linguagem como uma das formas de comunicar do ser humano, que é complexa e colabora com as relações cotidianas. $\mathrm{O}$ universo de valores presente na vida das comunidades é revelado pela linguagem que atua como um mapa que permite localizar a forma de pensar e identificar o mundo. De fato, por meio da linguagem é possível o diálogo com o mundo. Tal processo de humanização, que se realiza com base no conhecimento, na linguagem e na ação, produz um saber que se situa diante das condiçóes materiais de produção da vida, nos valores e no sentido atribuído à existência. Essa realidade mostra que o agir humano vai além da pura materialidade. A preservaçáo das experiências passadas, a memória coletiva da sociedade, mediada pela linguagem, torna possível a vida humana. Assim, o desenvolvimento de uma prática impregnada pela reflexão é que permite que se ganhe consistência na capacidade de interpretar, nomear e significar as coisas do mundo e a própria relação com elas.

Estabelecendo que linguagem religiosa, por natureza, seja uma linguagem simbólico-evocativa, celebrativa, comunitária e narrativa, por sua vez, verifica-se que a 
linguagem denuncia a mentalidade subjacente ao discurso, às vezes de forma mais clara do que aquilo que se intenta dizer por meio dela; pois é sintoma do pensar e viver de cada um. Pode-se falar contra o preconceito e mostrar, ao mesmo tempo, quanto se é preconceituoso mediante as expressóes utilizadas.

Ao organizar cada unidade nos diferentes segmentos escolares com a perspectiva de uma aprendizagem por aquisição de conhecimentos, é importante estabelecer um processo de iniciação sobre permita compreender esta cultura religiosa (Catáo, 1991, pp. 12-16) nas diferentes tradiçóes. Assim, ao perceber a religião como uma forma de expressão do fenômeno religioso, que ocorre em uma cultura ou culturas, compreende-se também o ambiente social como um agente que contribui e interfere na avaliação do mundo e das pessoas na dimensáo da expressão religiosa como, por exemplo, nas opções dos sujeitos, na construção de uma expressão própria, na confirmação de uma religiáo ou na adesão a uma nova. Prova disso é a constituição de sociedades pluralistas, formadas por cidadãos que têm entre suas características a vivência de filosofias ou religiōes, que interferem nas relações interpessoais.

Como disciplina acadêmica de perspectiva empírica, a Ciência da Religiáo investiga sistematicamente as religiôes em todas as suas manifestações. Um elemento chave é o compromisso de seus representantes com o ideal da neutralidade frente aos objetos de estudo, também chamado de agnosticismo metodológico. Não se questiona a "verdade" ou a "qualidade" de uma religiáo. Do ponto de vista metodológico, religióes sáo "sistemas de sentido formalmente idênticos", ainda que se expressasse com uma riqueza de diversidade. É especificamente esse princípio metateórico que distingue a Ciência da Religiáo da Teologia, e a aproxima de outras ciências humanas e sociais, como a Antropologia, a História e a Sociologia (Usarski, 2002, pp.01-02).

É importante ao Ensino Religioso focalizar os fundamentos humanos da questão religiosa, o que deve ficar evidente na linguagem utilizada por seus interlocutores no exercício educativo (Oliveira et al., 2007, pp. 117-119). Ou seja, a linguagem no Ensino Religioso contribuirá para que o estudante entenda o meio pelo qual seu grupo social interpreta a sociedade, os princípios morais que orientam muitas vezes a sua existência e os paradigmas indicadores da interpretaçấo social, a partir visão de mundo das tradiçóes.

\section{Consideraçóes}

Há poucas dezenas de anos, a questão problemática da linguagem aparentemente não existia de forma explícita na sociedade brasileira, que possuía uma autoimagem de homogeneidade como uma sociedade de cristandade. Quase todos falavam a mesma linguagem mono-religiosa ou a entendiam. Porém, ao assumir e cultivar o direito de se assumir como uma sociedade pluralista dialogante, exige-se revisitar a concepçáo de diversidade nacional, aprendendo a expressar as convicções em duas linguagens não tolamente iguais: o da comunidade de fé e o da sociedade plural (Oliveira et al., 2007, pp. 117-119).

Portanto, verifica-se que a linguagem religiosa necessita de ajustes para poder expressar os mais diversos temas, pois as diferentes estruturas linguísticas são limitadas 
para expressar as sutilezas e compreensões propostas pelas diferentes tradições religiosas. Em decorrência da experiência de fé dos grupos que são vivenciadas coletivamente, nem sempre é possível sistematizar por meio dos grupos linguísticos; por este motivo, a compreensáo básica da linguagem religiosa passa pelo território da analogia e da representação simbólica. Um exemplo desse processo é explicitado no documento Catequese Renovado da Conferência dos Bispos do Brasil (1983), que afirma o fato de que, ao expressar as relaçóes com Deus por meio de pessoas, gestos, palavras e silêncios, por serem sinais e símbolos, requer-se uma iniciação para a devida compreensão e vivência (Catequese Renovada, 1983, pp. 219-222).

Essa iniciação envolve o significado de gestos, cores, imagens (plásticas e verbais), objetos, atitudes, comparaçóes, parábolas, lembranças afetivas, monumentos históricos, poesia e alegorias.

Em cada segmento escolar é possível verificar estratégias para que os estudantes compreendam essa construção linguística. Por exemplo, na pré-escola é possível usar jogos dramáticos de expressão corporal e mímica, cançóes e histórias que as crianças podem acompanhar com gestos, favorecendo expressóes de festas cívico-religiosas, assim como criar símbolos e conhecer os diferentes símbolos das instituiçóes (Cruz, 1995, pp. 55-60).

A experiência religiosa gera a elaboração de uma linguagem para expressar ideias e sentimentos. $\mathrm{O}$ espaço escolar do Ensino Religioso não é proposto para realização de atos de fé, mas é uma oportunidade de decodificar as expressóes da realidade dos estudantes para que identifiquem, compreendam e respeitem a pluralidade religiosa na sociedade. Mais do que a linguagem, o que se pretende é a valorização dos indivíduos e uma convivência respeitosa. Para tal, reconhecer as concepçóes é importante para a socializaçáo desse fenômeno social e o reconhecimento da presença das tradiçóes religiosas na sociedade. Considerando que essa comunicação não ocorre apenas por palavras - muito é expresso por gestos, atitudes e, mesmo, pelo silêncio. Ou seja, transmite-se respeito ou intolerância pela fala e o que se expressa é resultado de do contexto-histórico-social-político-cultural. Como instrumento de comunicação, a linguagem expressa o que há na mente e, consequentemente, pode acolher ou rechaçar. Efetivamente, é mecanismo de relaçóes sociais (Gruen, 1995, pp. 137-140).

No processo de aprendizagem, como já verificado, a linguagem é a relação com pensamento estabelecido por meio de uma construção conceitual e, na questão religiosa, é necessária para ser sistematizar os conceitos do ensino religioso. Por meio de um componente curricular é possível a compressão do conhecimento social, que é o último e mais complexo tipo de conhecimento que as crianças aprendem a adquirir. A aquisição do conhecimento social depende de um entendimento das formas pelas quais os indivíduos se comunicam e criam laços. Isso se deve ao fato de que esse tipo de conhecimento requer uma compreensão complexa de emoçóes humanas e estímulos sociais. Conforme as crianças desenvolvem a capacidade de absorver o conhecimento social, acrescentam esta habilidade ao seu repertório de tipos de conhecimento, em vez de substituir habilidades de aquisição de conhecimento previamente adquiridas.

De fato, é significativo que o professor de Ensino Religioso favoreça o uso da linguagem adequada e organize um quadro ou pesquisa das tradiçôes religiosa para evitar 
a exclusão de algumas delas. Ao possibilitar aos estudantes falarem de sua tradiçãoo religiosa, o professor precisa propor que isto aconteça como troca de conhecimento, de entendimento do outro. Em geral, isso não representa problema, mas, para evitar manifestaçôes fervorosas, é importante que, assim como o professor, o estudante seja orientando para uma linguagem adequada ao processo de releitura, de entendimento, de superaçáo de conflitos, reconhecendo o Ensino Religioso como área de conhecimento.

A linguagem do professor, sua maneira de comunicar e explorar uma temática, precisa servir para que tanto estudante quanto professor possam adquirir e construir conhecimentos respeitando as diferenças (Olenick; Daldegan, 2003, pp. 44-46). Essa linguagem, nas aulas de Ensino Religioso, favorece o diálogo com os diferentes. Porém, por ser uma forma de comunicação, o professor precisa estar atento para a sua comunicação não verbal, que se utiliza do corpo, que pode ser apoio de complementação da linguagem ou da contradição. Assim sendo, a linguagem deve ser universal, partindo do princípio de que o professor não poderá generalizar sua fala, nem ao menos fazer prevalecer uma tradição religiosa.

O estudo sobre a linguagem no ensino religioso é ainda um processo inicial e, nesta etapa, procurou-se apontar aspectos iniciais da linguagem do Ensino Religioso a partir de produções entre 1991 e 2015.

Considerando os marcos normativos e, em conformidade com as competências gerais estabelecidas no âmbito da BNCC, o Ensino Religioso deve atender aos seguintes objetivos: a) Proporcionar a aprendizagem dos conhecimentos religiosos, culturais e estéticos, a partir das manifestaçōes religiosas percebidas na realidade dos educandos; b) Propiciar conhecimentos sobre o direito à liberdade de consciência e de crença, no constante propósito de promoção dos direitos humanos; c) Desenvolver competências e habilidades que contribuam para o diálogo entre perspectivas religiosas e seculares de vida, exercitando o respeito à liberdade de concepçôes e o pluralismo de ideias, de acordo com a Constituição Federal; d) Contribuir para que os educandos construam seus sentidos pessoais de vida a partir de valores, princípios éticos e da cidadania.

Com certeza a partir dessa sistematizaçáo, serão ainda necessários estudos e pesquisas empíricas para aprofundar a questão da linguagem no ensino religioso no espaço escolar.

\section{Referências}

AMATUZZI, M. A legitimidade psicológica da linguagem religiosa. Revista Estudos de Psicologia. v. 20, n. 1, p. 61-71, 2003.

ARISTÓTELES. Politica 1, 2, 1253. Disponível em: http://www.dhnet.org.br/ direitos/anthist/marcos/hdh aristoteles a politica.pdf. Acesso: 4 jan. 2017.

BAHNSEN, G. L. O problema da linguagem religiosa. Disponível em: http://www. monergismo.com/textos/apologetica/problema-linguagem-religiosa-parte1 banhsen. pdf. Acesso em 9 set. 2017.

BOAS, A. V.; MANZATTO, A. Teologia e Literatura: metodologias ativas. Revista Teoliterária, São Paulo; Campinas; Curitiba, v. 5, n. 10, pp. 08-13, 2015. 
CANDIDO, V. C. Haveria um jogo de linguagem específico para o Ensino Religioso? - uma análise dos Parâmetros curriculares nacionais para o ER como fonte do discurso dessa disciplina. Encontro Nacional de História das Religióes, Maringá, 2007.

CATÃO, F. A linguagem do Ensino Religioso. Revista de Catequese. n. 56, 1991, pp. 3-16.

CATÃO, F. A natureza do Ensino Religioso: a luz de uma aula. Revista de Catequese, v. 11, n. 44, 1998, pp. 5-16.

CHEVALIER, J; GHEERBRANT, A. Verbete Linguagem. In: Dicionário de símbolos. 12. Edição. Rio de Janeiro: Jose Olympio, 1998, pp. 551-552.

CONFERÊNCIA NACIONAL DOS BISPOS DO BRASIL. Catequese Renovada. São Paulo: Paulinas, 1983.

CONSELHO NACIONAL DE EDUCAÇÃO. CNE/CEB nº 5/97. Distrito Federal: CNE, 1997.

CRUZ, J; GOMES, E. A linguagem simbólica como proposta metodológica para o Ensino Religioso. II Seminário FIDELID: Diálogo e reflexão do Ensino Religioso na escola, João Pessoa, 2015.

CRUZ, T. M. L. Prática de educação religiosa: Por onde começar? São Paulo: FTD, 1987.

CRUZ, T. M. L.; ESTAL, M. A. Religião na escola: um assunto importante. Questionamentos e Metodologia do ensino Religioso. São Paulo: FTD, São Paulo, 1995.

DOMINGUES, G. Cultura e linguagem: em busca da diversidade no currículo do Ensino Religioso. Saláo de Pesquisa. São Leopoldo: Faculdades EST, 2011.

DOMINGUES, G. Cultura e linguagem: em busca da diversidade no currículo do Ensino Religioso. Salão de Pesquisa. São Leopoldo: Faculdades EST, 2011.

FRAISSE, P.; PIAGET, J. Tratado de Psicologia Experimental. v. VIII. Sáo Paulo: Forense, 1969.

GRUEN, W. A natureza do Ensino Religioso: a luz de uma aula. Revista de Catequese, v. 11, n. 44, 1998, pp. 5-16.

GRUEN, W. O ensino religioso na escola. Petrópolis: Vozes, 1995.

JUNQUEIRA, S. et al. Socialização do saber: produção científica do Ensino Religioso. Porto Alegre: Editora FI, 2018.

KOCH, S. Discurso e Ensino Religioso: um olhar a partir da diferença. Blumenau: FURB, 2007. 
KOCH, S. R. Discurso e Ensino religioso: um olhar a partir da diferença. Educação. FURB. 2007.

KOCH, S.; FONTANIVE, D.; CECCHETTI, E. Linguagem, diferença e dignidade: espaços e encontros na diversidade. III Simpósio Internacional sobre Religiosidades, Diálogos Culturais e hibridaçóes, Dourados, 2009.

LOPES, M. M. A sensibilidade na tradução de textos sagrados. Todas as letras, v.11, n. 2, 2009, pp. 61-73.

LOPES, M. M. Traduzindo o sagrado: a linguagem religiosa à luz de uma consciência lingüística. Cadernos de Pós-Graduação em Letras, São Paulo, v. 7, n. 1, pp. 01-10, 2016.

LUSSI, C. A linguagem no fazer teológico: elementos do legado de Rahner sobre literatura e poesia. Revista Teoliterária. São Paulo, Campinas, Curitiba, v. 1, n. 2, pp. 68-86, 2011.

MELO, A. Linguagem e Sincretismo: Reflexos no Ensino Religioso. IV Congresso da ANPTECRE, Recife, 2013.

MESLIN, M. A experiência humana do divino: fundamentos de uma antropologia religiosa. Petrópolis: Vozes, 1992.

MINISTÉRIO DA EDUCAÇÃO. Base Nacional Comum Curricular. Distrito Federal: MEC, 2017.

MINISTÉRIO DA EDUCAÇÃO. PCN - Ensino Médio - Bases Legais Distrito Federal. Distrito Federal: MEC, 1997.

MOCELLIN, T. A linguagem no Ensino Religioso: limites e possibilidades. Encontro Nacional de História das Religióes, Maringá, 2007.

MONTOYA, A. O. Pensamento e linguagem: percurso piagetiano de investigação. Psicologia em Estudo, v. 11, n. 1, pp. 119-127, 2006.

OLENIKI, M.; DALDEGAN, V. M. Encantar: uma prática pedagógica no ensino Religioso. Petrópolis: Vozes, 2003.

OLIVEIRA, E. T. Fundamentos epistemológicos do Ensino Religioso. Curitiba: Ibpex, 2009.

OLIVEIRA, L.; KOCH, S. Linguagem e diferença: espaços e encontros na formação em Ensino Religioso. Diálogo Educacional, São Paulo; Curitiba,. v. 8, n. 23, pp. 245-262, 2008.

OLIVEIRA, M. K. Vygotsky: aprendizado e desenvolvimento um processo histórico. São Paulo: Scipione, 1993.

OLIVEIRA. L. Et al. Ensino Religioso no Ensino Fundamental. São Paulo: Cortez, 2007. 
PINTO, P. M. Linguagem e Religião: um jogo, de racionalidade, de identidade, de fundamentos. Revista de Estudos da Religão, São Bernardo do Campo, n. 4, pp. 81-98, 2002.

RABUSKE, E.A. A linguagem religiosa: algumas consideraçôes introdutórias. Letras de Hoje, v. 29, n. 2, pp. 147-158, 1984.

SASTRE, J. Nuevo Diccionario de Catequética. v. 02. Madrid: San Pablo, 1999, pp. 1353-1369.

SAUER, R. Lenguage Religiosa. PEDROSA. V.; NAVARRO, Ma; LÁZARO, R.;

SETZER, R. Os homens estão criando um mundo que Deus não quer; contradição e conflito no discurso religioso. In: ORLANDI, E. P. Palavra, fé e poder. Campinas: Pontes, 1987, pp. 91-102.

SHOCK, M. Aportes epistemológicos para o Ensino Religioso: um estudo analítico-propositivo. São Leopoldo: EST; Clube de Autores, 2012.

SIQUEIRA, G. Linguagem do Ensino Religioso. Dissertação. Alfenas: Universidade de Alfenas, 1998.

TRENTI, Z. La religione como disciplina scolastica. La scelta ermeneutíca. Leumann: Elle di Ci, 1990.

USARSKI, F. Interações entre Ciência e Religião (entrevista com Frank Usarski). Revista Eletrônica Espaço Acadêmico, v. II, n. 17, outubro, 2002. Disponível em https://www.academia.edu/9666015/Entrevista Intera\%C3\%A7\%C3\%B5es entre Ci\%C3\%AAncia e Religi\%C3\%A3o. Acesso em: 23 set. 2017.

VYGOTSKY, L. Pensamento e linguagem. Lisboa: Ridendo Castigat Mores, 2002.

Recebido: 10 de fevereiro de 2018.

Aprovado: 6 de junho de 2018. 